\title{
Impact of shifting cultivation on mammalian diversity and distribution in fringe areas of Dampa tiger reserve, Mizoram, India
}

\author{
Gouda Sushanto, Decemson Ht. , Parida Abinash and Solanki G.S. 四
}

Received: 02.01.2020

Accepted: 14.02.2020

\begin{abstract}
Shifting cultivation is a largely practiced agricultural technique in the north-eastern part of India. This has led the fragmentation of natural habitat for wildlife species. Impact of jhum cultivation on distribution of mammalian species was studied through transect survey for scat, camera trapping, and burrow counting. Barking deer (27\%) and wild boar (24\%) were most frequent visitors. Among the carnivores highest abundance (3-5 scat samples per jhum field) was recorded for leopard cat and Indian Palm civet. 2-5 years old abandoned jhum fields were recorded to be suitable habitat for movement of large herbivores. The frequency of scat decreased with age of the jhum $>5$ yrs. Road sides, trails and primary forest near the active jhum forest were actively visited by clouded leopard. The encounter rate for active and old burrows of rodents were highest in 1-2 years old/ recently abandoned jhum fields with a rate of $3.56 \mathrm{~km}^{2}$ and $2.68 \mathrm{~km}$ respectively. Camera trapping also resulted in 36 images of different animal species. Increased spatial heterogeneity promotes mammalian distribution.
\end{abstract}

Keywords: Abandoned land, encounter rate, jhum cultivation, mammalian diversity, mammalian distribution, spatial heterogeneity

\section{Introduction}

Shifting cultivation, locally known as Jhum cultivation is a traditionally followed agriculture practice supporting the livelihood for over 0.44 million tribal families $(86 \%)$ of the total population across the north-eastern states of India (Yadav, 2013). Shifting cultivation has been practicing by several other indigenous communities of tropical landscape in the Asian sub-continent including Bangladesh (Rahman et al., 2011), Vietnam (Do et al., 2010), Thailand (Khisa and Mohiuddin, 2015), Malaysia (Kendawang et al., 2004) and even in Mexico (Dalle et al., 2011), Brazil (NaughtonTreves et al., 2003), Guatemala (Ferguson et al., 2001) and Central African rain forest countries (Gemerden et al., 2003). Forest cover in the state of Mizoram is about $86.27 \%$ of geographical area as on 2015 according to FSI report 2017. However, the forests have suffered serious depletion and degradation due to shifting cultivation, uncontrolled fire, unregulated felling of tree etc. resulting a loss of $531 \mathrm{~km}^{2}$ forest cover as assessment by FSI in 2017. The 15-20 years cycle of jhum cultivation.

\section{Author's Address}

Department of Zoology, Mizoram University, Tanhril-796004, Aizawl, Mizoram, India

E-mail.: drghanshyam.solanki@gmail.com gssolanki02@yahoo.co.in

period earlier on forest lands has reduced to 2 to 3 years now. The decadal rate of decrease in cycle of jhum and cultivated area is $0.15 \%$ per year (Adhikary et al., 2019). Further increase in population has caused replacement of shifting fields by monoculture plantations such as teak, oil palm, betel and rubber (Raman, 2001; Mandal and Raman, 2016). Shifting cultivation is a subject of debate till date as some ecologists questions the sustainability of the shifting practice due to clearing of primary and secondary forests, while others supports its existence when compared to monoculture, and other economic-oriented activities that are more critical drivers of deforestation, soil erosion and biodiversity loss. Although literatures are available quantifying the impact, changes and recovery pattern in floral and avifaunal diversity across successional gradient following shifting cultivation (Mandal and Raman, 2016; Raman, 2001), there has been a great paucity of research on the impact and recovery pattern of mammalian species. Teegalapalli et al. (2009) reported that till 2009 only 6 studies were available worldwide that were undertaken to understand the persistence of mammals in secondary forests developed due to shifting cultivation. Mammal 
species such as elephants, primates, barking deer, squirrels and other small species that are generally adapted to habitat disturbance have been reported to be primary visitors and abundant in successional sites whereas specialist frugivore and foliovore species are mostly restricted to the mature forest. Occasional trespassing of bear's is also reported in some cases (Reid, 1997; Yadav et al., 2012; Medellin and Equihua, 1998; Solanki et al., 2016). Garden or bush-meat hunting is stated to responsible for the reduction in number of small mammals mainly in these crop fields (NaughtonTreves et al., 2003; Mukul and Herbohn, 2016; Omeja et al., 2016). Considering the fast changing landscape and alteration in cropping pattern in the region, the study was undertaken to determine the recovery and distribution of mammalian species and the potential impacts of shifting cultivation in buffer area and in vicinity of Dampa Tiger Reserve, one of the largest protected areas of Mizoram.

\section{Material and Methods \\ Study area}

The study was carried out in the peripheral areas including buffer zone of Dampa Tiger Reserve (DTR) situated at the western limit of the state of Mizoram, India. DTR has great significant as it falls in the Indo-Myanmar biodiversity hotspot region. The geographical location of reserve lies within $23^{\circ} 32^{\prime} 42^{\prime \prime}-23^{\circ} 41^{\prime} 36^{\prime \prime}$ North latitude and $92^{\circ} 13^{\prime} 12^{\prime \prime}-92^{\circ} 27^{\prime} 27^{\prime \prime}$ East longitude and has 500 $\mathrm{km}^{2}$ (core) and a buffer area of $448 \mathrm{~km}^{2}$. It shares the international boundary with Bangladesh on western side. The reserve is divided into two ranges namely the Teirei Forest division and the Phuldungsei division. There are about 15 villages within buffer area of DTR, Nine villages were initially selected (Table 1) and eight villages were finally identified for this study which are mainly practises shifting cultivation for their sustenance. The study areas were further categorized into different ages of jhum fields and plantation sites inside buffer and peripheral areas of DTR (table 2 $\&$ Plate 1). The region is inhabited roughly 22,000 individuals from the Mizo, Reang (Bru) and the Chakma communities (Census of India, 2011). The livelihood of the locals is mostly depended on agriculture and other forest based resources (Lalrinchhana and Solanki, 2015; Sahoo et al.,
2010). The natural vegetation of tiger reserve is tropical rain forest type that supports a diverse faunal species that include clouded leopard, Phayre's leaf monkey, Malayan sun bear etc. (Singh and Macdonald, 2017; Gouda et al. 2016) that often sneak in to jhum fields for feeding opportunities. Several rare and endangered floral species like Begonia dampae sp., Globba spathulata and Hemiorchis pantlingii are also found around Dampa TR (Odyuo et al., 2018; Kumar and Singh, 2018).

\section{Data collection}

Data on mammalian species visiting agricultural crop fields and forest patches in surrounding areas of DTR was determined following a questionnaire survey and on transect survey methods during the period of September 2018 to June 2019.

Information on visiting of mammals to jhum fields, livelihood status of locals, land size and other alternative sources of income, distance from protected area, crop damage and depredation by mammals, hunting and usage of ethno-faunal resources etc. was collected through semistructured questionnaire survey. Both open end and closed end questions were involved in the questionnaire survey (Appendix I). Male respondents were mostly targeted for the survey as they spend most of their time in crop fields while female respondents also gave important input on issues of crop depredation.

\section{Mammalian survey}

Mammalian species and their distribution within the study sites were determined through transect surveys and direct observation during trails walk. 24 transects were walked covering different ages of shifting cultivation, perennial streams, forest ages, plantation sites etc. The transect length was varies from 1-3 km depending on the forest type. $9.1 \mathrm{~km}$ were walked in current jhum, $21.6 \mathrm{~km}$ in $1-2 \mathrm{yrs}$ old jhum fields, $7 \mathrm{~km}$ in 3-5 yrs old forest and $9 \mathrm{~km}$ in plantation sites. Variation in transect length was due to vegetation types in jhum area. In the survey, indirect evidences for presence of mammalian signs such as foot marks, claw marks, scats/ pellets, food remains etc. were extensively searched and collected along with their locations with help of hand held GPS. Scat samples were identified through specific characteristic features such as colour, length and width, single dropping or multiple combination of feature (Farrell et al., 
2000; Walsh, 2015). The presence of hairs, food item (berries, seeds, insect wings, bones etc.), time and place of occurrence were also recorded to get a general idea about the animal present in the region. Relatively decomposed scat samples were avoided from collection, but there GPS position was recorded so as to prepare the distribution map for mammalian species around DTR. Burrows of rodents were counted and categorized as active burrow and old/ abandoned based on their morphological characteristic. Foot marks of mammals were identified through field guides suggested by Apeldoorn et al., (1993). Distribution of mammalian species was determined through the encounter rate and abundance of indirect evidences as follows;
Abundance $=\frac{\text { Total number of the animal signs }}{\text { No. of quadrate in which they occur }} \times 100$

Encounter rate $(\%)=\frac{\text { Total number of the animal signs }}{\text { Total distance cover in the survey }} \times 100$

\section{Camera trapping}

The presence of mammalian species in different ages of shifting crop fields was studied through camera trapping method (Schmeller, 2015; Steenweg et al., 2017; Rich et al., 2019). Camera traps were placed at appropriate heights along trails with animal signs in various forest habitats such as abandoned crop fields, fallows and small water streams for photo-capturing of mammalian species.

Table 1: Surveyed villages in vicinity of DRT along the household structure of the villages

\begin{tabular}{|c|c|c|c|c|c|}
\hline SN & Village & GPS position & Altitude (m) & $\begin{array}{l}\text { Distance from } \\
\text { DTR }(\mathrm{km})\end{array}$ & $\begin{array}{l}\text { No. of } \\
\text { houses }\end{array}$ \\
\hline 1 & Phuldungsei & $\mathrm{N} 23^{\circ} 30^{\prime} 01.5$ E $92^{\circ} 25^{\prime} 03.0$ & 905 & 0.7 & 350 \\
\hline 2 & Saithah & $\mathrm{N} 23^{\circ} 34^{\prime} 74.7$ E $92^{\circ} 26^{\prime} 19.9$ & 809 & 0.6 & 85 \\
\hline 3 & Lallen & 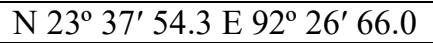 & 774 & 1.2 & 170 \\
\hline 4 & Tuipuibari & 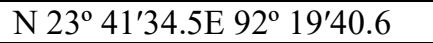 & 298 & 2 & 408 \\
\hline 5 & Serhmun & $\mathrm{N} 23^{\circ} 41^{\prime} 52.1 \mathrm{E} 92^{\circ} 21^{\prime} 33.4$ & 728 & 3 & 157 \\
\hline 6 & Damparengpui & $\mathrm{N} 23^{\circ} 42^{\prime} 18.2$ E $92^{\circ} 23^{\prime} 20.3$ & 439 & 0 & 402 \\
\hline 7 & Khawhnai & $\mathrm{N} 23^{\circ} 43^{\prime} 25.2$ E $92^{\circ} 26^{\prime} 27.3$ & 225 & 2 & 81 \\
\hline 8 & Teirei & $\mathrm{N} 23^{\circ} 41^{\prime} 32.6$ E $92^{\circ} 27^{\prime} 03.6$ & 260 & 0 & 87 \\
\hline 9 & West Phaileng & $\mathrm{N} 23^{\circ} 42^{\prime} 16.9$ E $92^{\circ} 28^{\prime} 10.6$ & 610 & 17 & 864 \\
\hline
\end{tabular}

Table 2: Age of jhum land and vegetation characteristics

\begin{tabular}{|l|l|}
\hline Age of Jhum & Characteristic features \\
\hline Current jhum & Completely burned without any ground flora except few burnt trees. \\
\hline 1 yr jhum & $\begin{array}{l}\text { Standing crop in form of paddy and other vegetables alongside with small perennial plants, } \\
\text { climbers and shrubs. Burned trees either standing or fallen can also be present. }\end{array}$ \\
\hline 5 to 10 yrs $j h u m$ & $\begin{array}{l}\text { Harvested jhum fields overtaken by herbs, climbers, grasses and woody shrubs dominated } \\
\text { by bamboo and canopy cover of over } 60 \%\end{array}$ \\
\hline 10 yrs and above & $\begin{array}{l}\text { Mixed bamboo forest with trees like Schima wallichi, Albizia chinensis, Deris robust, } \\
\text { Albizia odoratisima, Ficus racemosa of basal width } 40 \text { to } 80 \mathrm{~cm} \text { and a canopy cover of } \\
\text { over } 80 \% .\end{array}$ \\
\hline
\end{tabular}

\section{Results and Discussion}

Vegetation feature in jhum land of different age classes.

In the buffer region of Dampa, diverse group of vegetation types were found with profound floral and faunal diversity. Around Dampa TR details of vegetation types in different age class of jhum field are described in table 2. Apart from the agricultural crop fields, several other plantation sites as rubber plantation, mixed farms (rubber, banana, pineapple etc.), teak plantation and oil palm were also recorded. Grasslands were also recorded in some low laying areas and along the natural streams of Khawhnai and Teirei village. Small patches of community owned forest were present in vicinity 
areas of the villages around the TR. This forest patches were used as sources of fuel wood, bamboo and collection of food items.

\section{Livelihood status and interaction with mammalian species}

Socio-economic status and interaction of locals with mammalian species was studied from 9 villages along the periphery of DTR. Details of surveyed villages are presented in table 1 . In the survey, 271 individuals from eight villages were interviewed and data on livelihood and land holding capacity were collected. The village Serhmun is in the process of relocation and was not covered in the survey. 134 individuals (49.44\%) possess more than a hector area of land, $88(32.47 \%)$ had less than a hector of agriculture land, while 49 persons $(18.08 \%)$ are dependent on other sources of income other than agriculture. The land holding details of the local people in the surveyed villages are presented in Fig. 1. Maximum number of individuals (36) having land holding more than one hectare are in Damparengpuii village followed by Phuldungsui (23) Saitha and Tuipuibari village with 19 individual each. Apart from agriculture, these forest dwellers are mostly dependent on forest resources for sustenance of daily activities. They collect fuel wood, timber, fodder for cattle's, grasses, medicinal plants, food items, bamboo etc. The proportion of usage of floral resources by local villagers in the villages surveyed as per the table 1 is shown in Fig. 2. While locals were found to be dependent on the entire forest products with $36.61 \%$; bamboo was found to be the most commonly used NTFP's product followed by food (bamboo shoots, leaves, barks, flowers etc.), fuel wood and timber with $29.46 \%, 17.34 \% 12.54 \%$, $4.05 \%$ respectively.

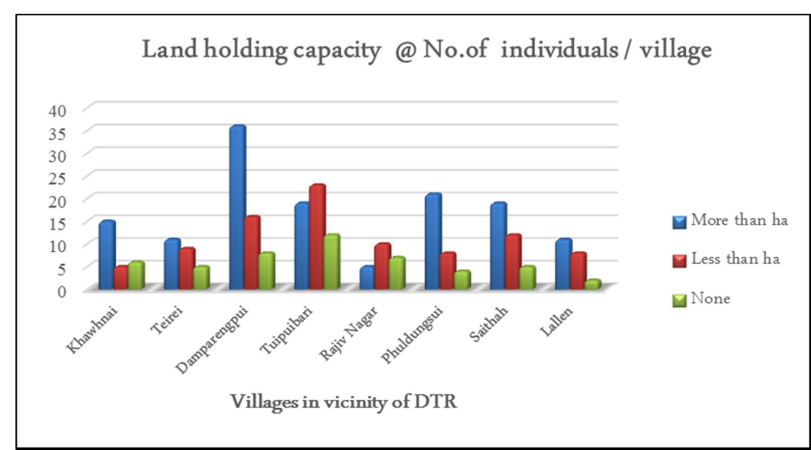

Fig. 1: Land holding capacity by local people for agricultural purposes around DTR

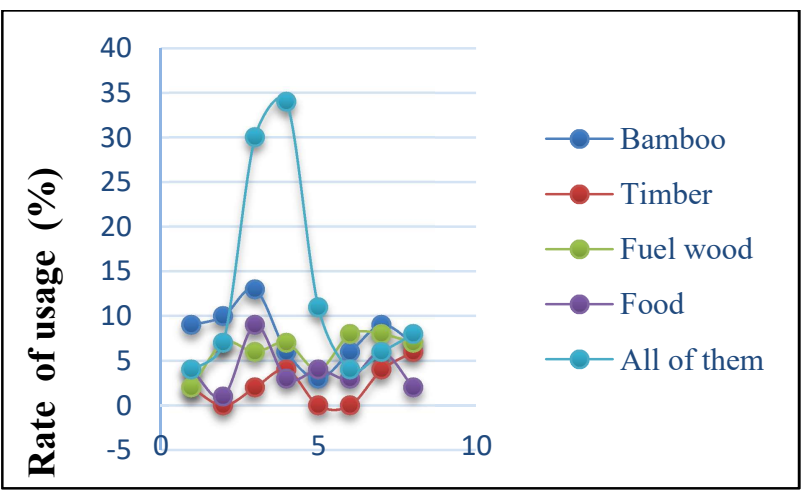

Fig. 2: Usage of forest resources in the studied villages (1-8 are serial number of village as per table 1).

The agricultural crop fields that are adjacent to the tiger reserve attract several wild mammalian species because variety of food source is available there. Several mammalian species were reported to visits these crop fields in search of food. Mammals like wild boar (Sus scrofa), barking deer (Muntiacus muntjak) and bears (black bear and sun bear) were stated by villagers to frequently raid jhum fields resulting in depredation and sometimes heavy crop damage and loss. Small carnivores like the Clouded leopard (Neofelic nebulosa) civets (Paradoxurus sp.), porcupine (Hystrix sp.), and leopard cats (Prionailurus bengalensis) are also attracted towards the rodents, jungle fowl, squirrels and other species that are abundant in such crop fields. Barking deer $(27 \%)$ and wild boar $(24 \%)$ were reported to the most frequent raiders to crop fields' causing maximum crop damage and also most common wildlife species enter in conflict with locals (Fig. 3).

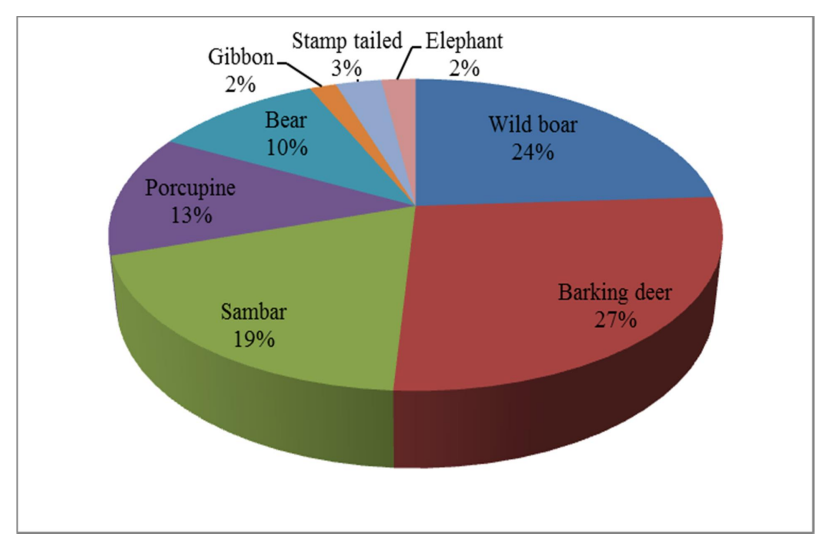

Fig. 3: Human-wildlife species (\%) in conflict with local farmers in their agriculture fields. 


\section{Mammalian distribution and composition}

During the survey period, a total of 102 scats samples in forms of pellet or dropping of different mammalian species namely Sambar (Rusa unicolor), barking deer (Muntiacus muntjak), Wild dog (Cuon alpinus), crab eating mongoose (Herpestes urva), clouded leopard (Neofelis nebulosa), leopard cat (Prionailurus bengalensis), Indian palm civet (Paradoxurus sp.) were collected. With help of GPS data about distribution of mammalian species a map was generated though GIS software showing the locations in $\mathrm{jhm}$ fields (Fig.6)

Currently burnt forest areas showed the least abundance of animal species as only 3 scat samples and some hoop marks were recorded. Active or recently abandoned agriculture crop fields were visited by herbivores like Sambar (Rusa unicolor), barking deer (Muntiacus muntjak) and Wild boar (Sus scrofa). Among the carnivores higher abundance (3-5 scat samples per jhum field) was recorded for leopard cat and Palm civet. Abandoned jhums were also specified as potential habitat for rodents, reptiles, small carnivore species, porcupines and avian species and also the lone elephant of Dampa. Evidences in forms of feathers of birds, peafowl and carcass of rodents hunted by wild animal's probable cats and civets and other food remains were common among jhum sites. Water bodies adjacent to crop field were found to serve as excellent source for detection of animal foot marks for species like crab eating mongoose (Herpestes urva), leopard cat (Prionailurus bengalensis), hog badger (Arctonyx collaris), barking deer (Muntiacus muntjak) etc. While grasslands were found to be ideal for small felids, rodents and civets; low laying water bodies (streams) with active water flow indicated the presence of crab eating mongoose (Herpestes urva), leopard cat (Prionailurus bengalensis) and sometimes clouded leopard (Neofelis nebulosa). 2-5 years abandoned agricultural crop fields' assists to be suitable habitat for movement of large herbivores and several birds (Black-throated Sunbird, long-tailed Nightjar, racket-tailed Drongo etc.) as it provide cover to them. Probability of finding a scat sample or other evidence tends to decrease with age of the jhum 5 yrs $>$ (Fig 4) (table 3 ). In the entire study period, highest number of scat samples were recorded for Indian palm civet (Paradoxurus sp.) followed by Sambar (Rusa unicolor) and leopard cat (Prionailurus bengalensis). Evidences of barking deer (Muntiacus muntjak) were found to be prominent in secondary bamboo forest or inter connecting forest patches in the buffer region of Dampa Tiger Reserve. Scats of clouded leopard (Neofelis nebulosa) and Dhole (Cuon alpinus) were also recorded in the survey along road sides, trails and primary forest near the active jhum forest. Survey is teak plantation sites resulted in zero signs of mammals. Rubber plantation and mixed farms (crops including banana, beetle, Parkisonia timontonria) have active burrows and higher density of birds and peafowls in comparison to teak plantations. Correlation between animal's frequency and distance of crop fields from DTR was found to be insignificant. Frequency of the animal species visiting the jhum fields in different villages were tested for one way ANOVA. The result was found significant $(\mathrm{P}<$ $0.05, F=7.73$ ) as species of wild boar, sambar, barking dear, jungle fowl are regular visitors in the jhum.

Table 3: Encounter rate for burrows in different ages of shifting cultivation

\begin{tabular}{|l|l|l|l|}
\hline Ages of jhum field & No of signs & $\begin{array}{l}\text { Encounter rate of Active } \\
\text { burrow }\left(\text { per } \mathbf{k m}^{2}\right)\end{array}$ & $\begin{array}{l}\text { Encounter rate of Old } \\
\text { burrow }\left(\text { per } \mathbf{k m}^{2}\right)\end{array}$ \\
\hline Current & $104 \pm 8.13$ & 1.20 & 3.84 \\
\hline $1-2$ yrs/ abandoned jhum & $126 \pm 5.01$ & 3.56 & 2.68 \\
\hline $3-5$ yrs & 8 & 0 & 0.4 \\
\hline 5 yrs $>$ & $49 \pm 6.67$ & 2.0 & 1.28 \\
\hline Plantation & $17 \pm 4.92$ & 1.5 & 1.6 \\
\hline
\end{tabular}


Table 4: List of wildlife species photo-captured through camera traps

\begin{tabular}{|l|l|l|l|l|}
\hline Common name & Scientific name & Food habit & IUCN status & No. of photo \\
\hline Indian Jackal & Canis aureus indicus & C & LC & 3 \\
\hline Sambar & Rusa unicolor & H & VU & 3 \\
\hline Crab eating mongoose & Herpestes urva & C & LC & 2 \\
\hline Leopard cat & Prionailurus bengalensis & C & LC & 3 \\
\hline Jungle cat & Felis chaus & C & LC & 1 \\
\hline Malayan sun bear & Helarctos malayanus & O & VU & 1 \\
\hline Indian palm Civet & $\begin{array}{l}\text { Paradoxurus } \\
\text { hermaphroditus }\end{array}$ & O & LC & 4 \\
\hline Un ID Squirrels & --- & H & -- & 2 \\
\hline Kalij pigeon & Lophura leucomelanos & O & LC & 4 \\
\hline Red jungle fowl & Gallus gallus & O & LC & 8 \\
\hline Un ID birds & --- & O & -- & 5 \\
\hline
\end{tabular}

Densities of burrows were determined to measure the density of rodents in the study area. The encounter rates for active and old burrows were highest in 1-2 years old/ recently abandoned jhum fields with a rate of $3.56 \mathrm{~km}^{2}$ and $2.68 \mathrm{~km}^{2}$ respectively (table 3 , Fig. 5). The encounter rate of active burrows in current jhum fields and plantation sites were relatively lower, while it was negative in 3 to 5 year's old forest. The chances to encounter both an active or old burrow tend to decrease with the age of the crop field.

Distribution records of animals based on Camera trapping
In the process of camera trapping, 36 images were obtained of different animal species, in which Red jungle fowl (Gallus gallus) contributed for the most $(22.2 \%)$ followed by Indian palm Civet (Paradoxurus hermaphroditus) (11\%), Indian Jackal (Canis aureus indicus) (8\%) and Sambar (Rusa unicolor) (8\%) (table 4). Several species of bird's species were also recorded through camera traps. Deployment of camera traps and images obtained will be crucial for confirmation of the available wild species in the later phase of the study. Some of the images obtained are shown in Plate 2.

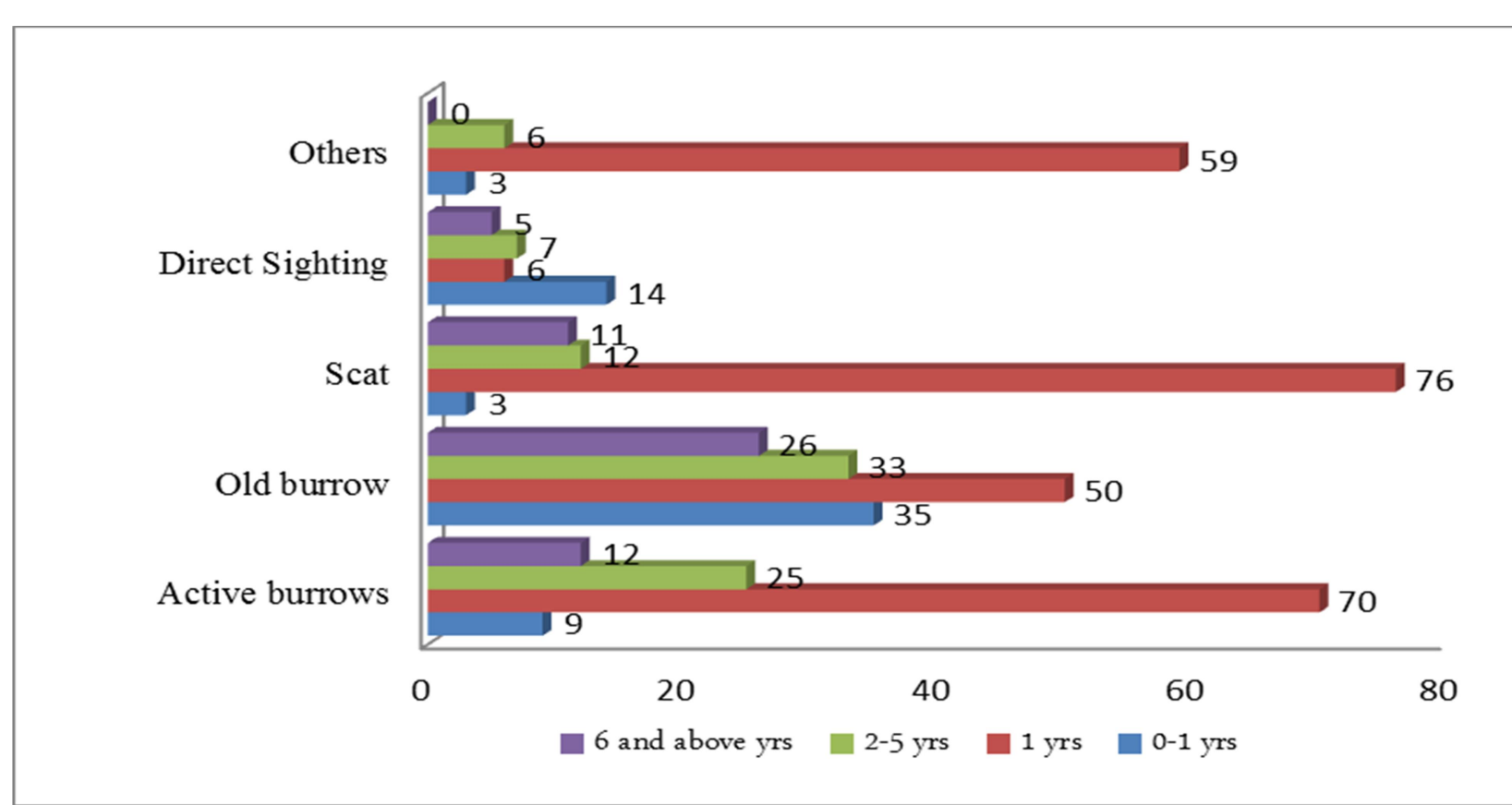

Fig. 4: Evidences of distribution of mammals in successional shifting fields 


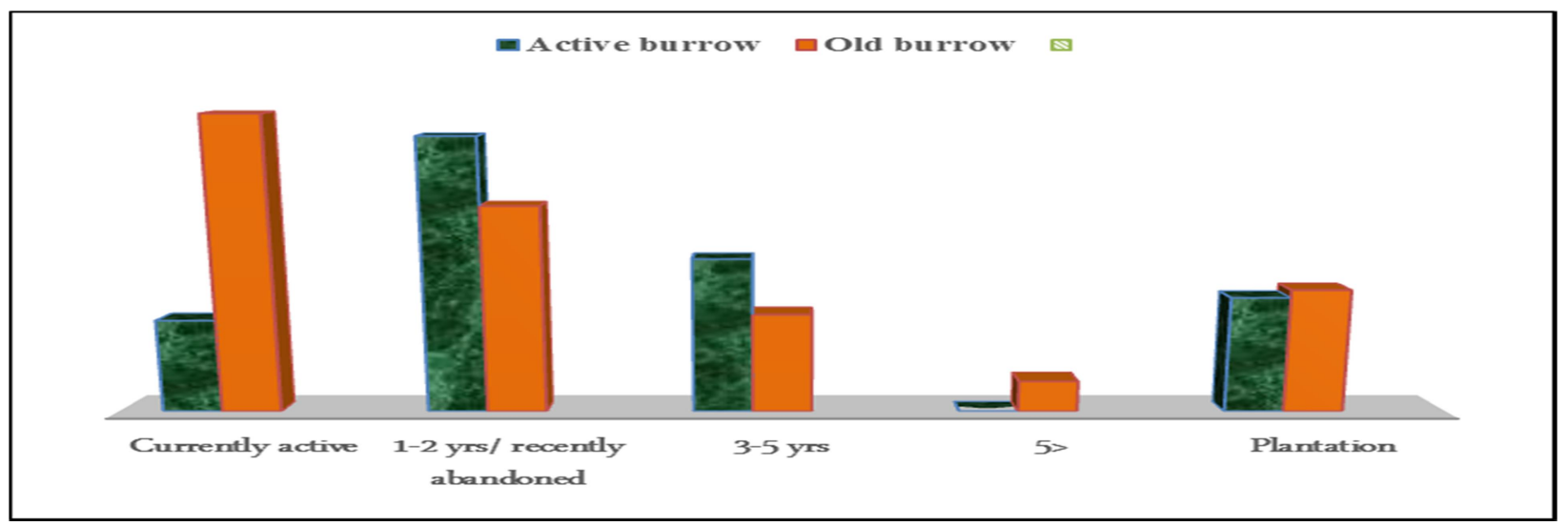

Fig. 5: Encounter of rodent burrows in different ages of shifting cultivation

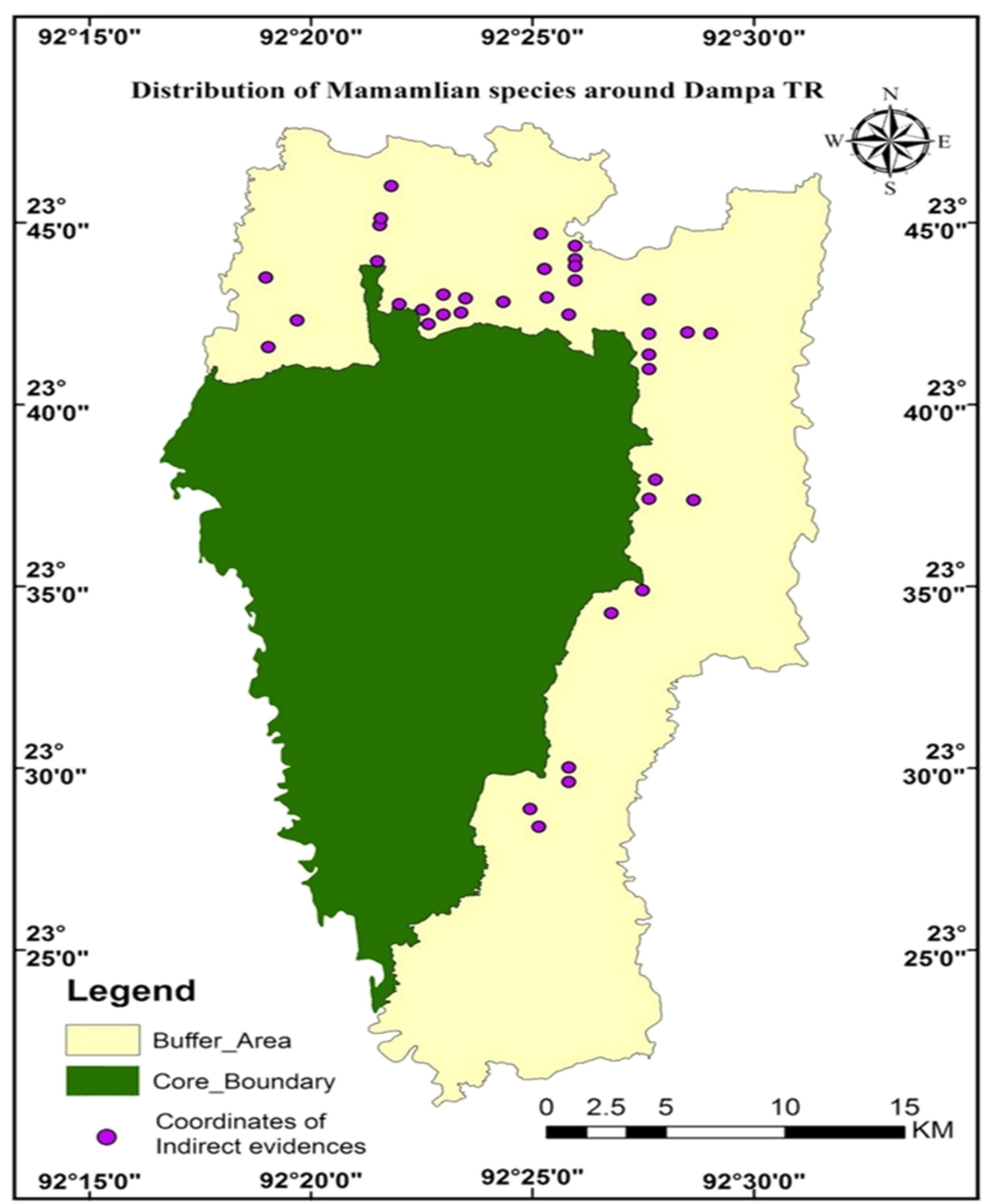

Fig. 6: Distribution of mammalian species in study area 


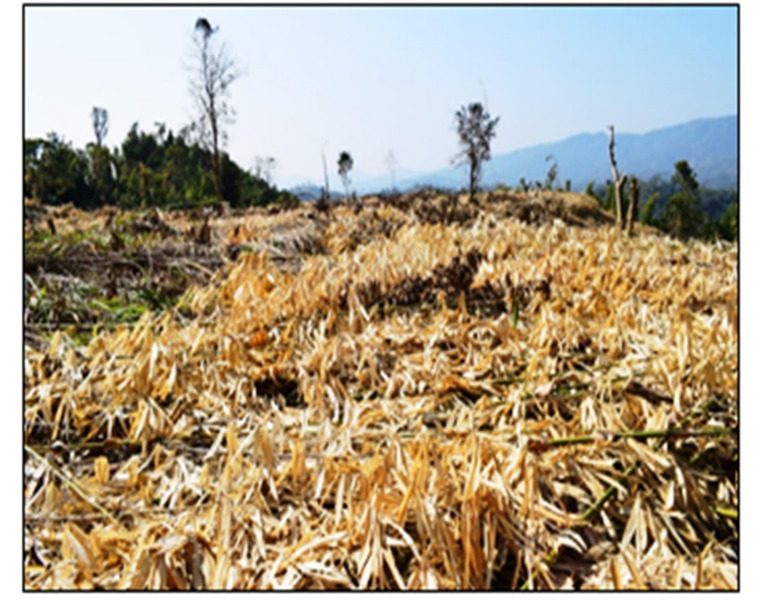

(a)

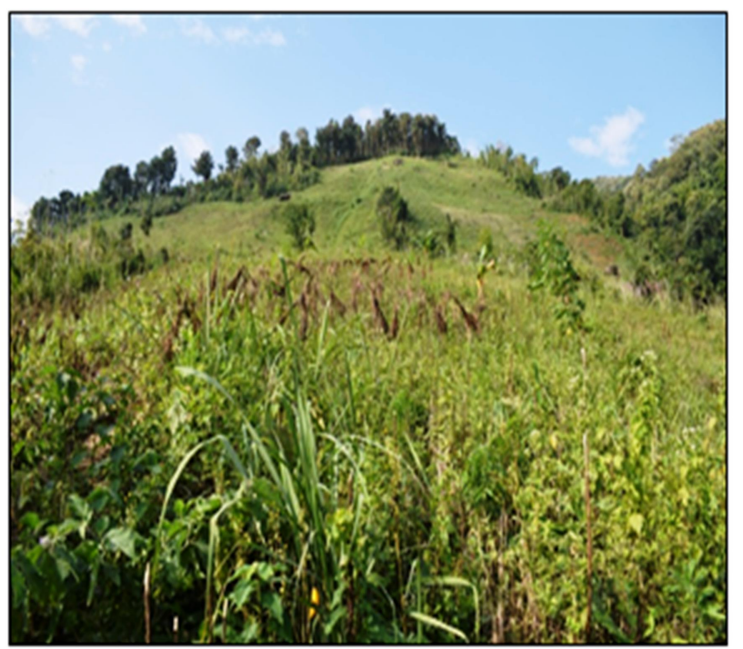

(d)

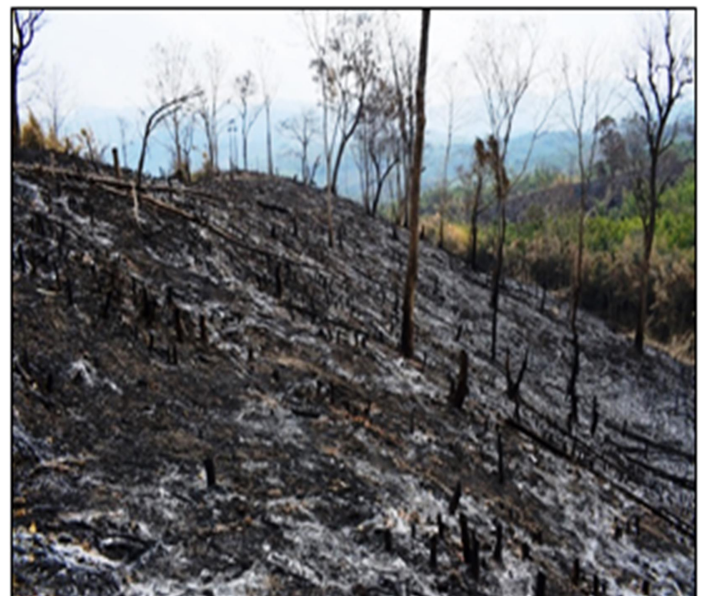

(b)

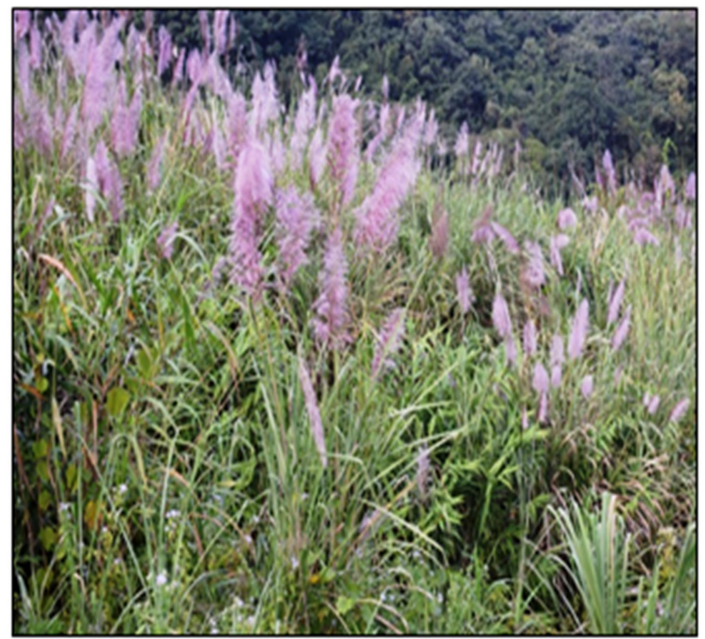

(e)

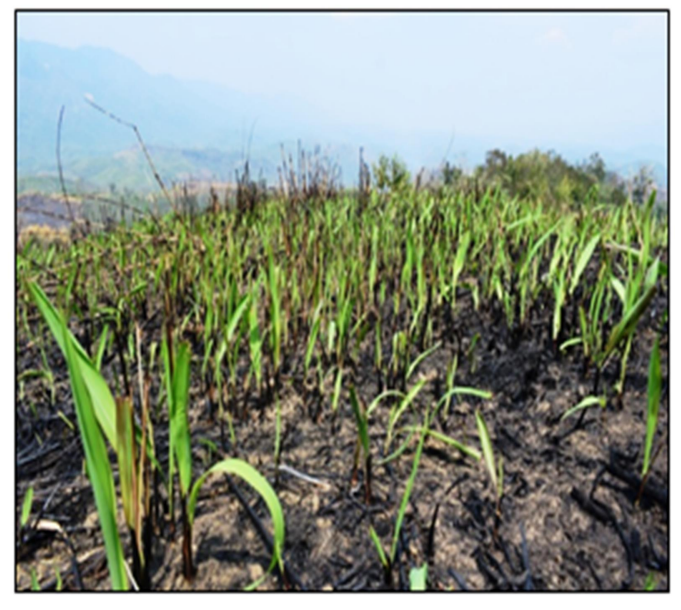

(c)

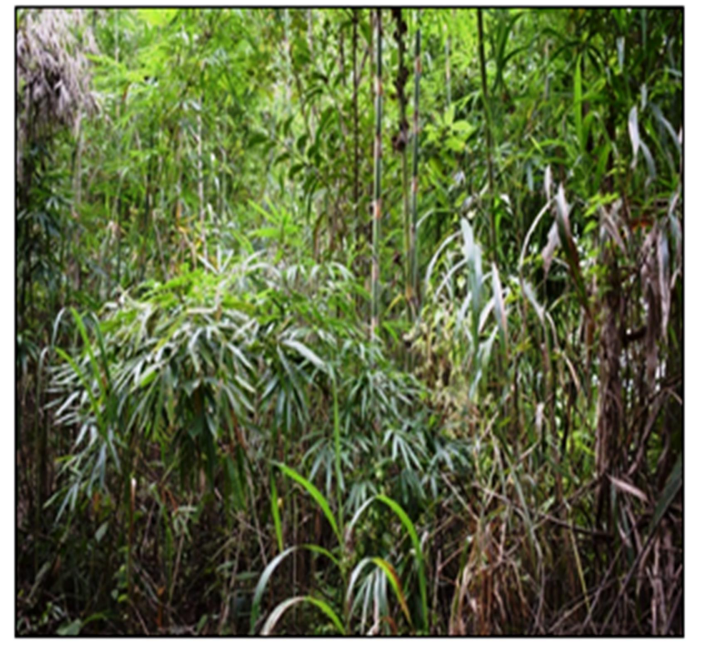

(f) 


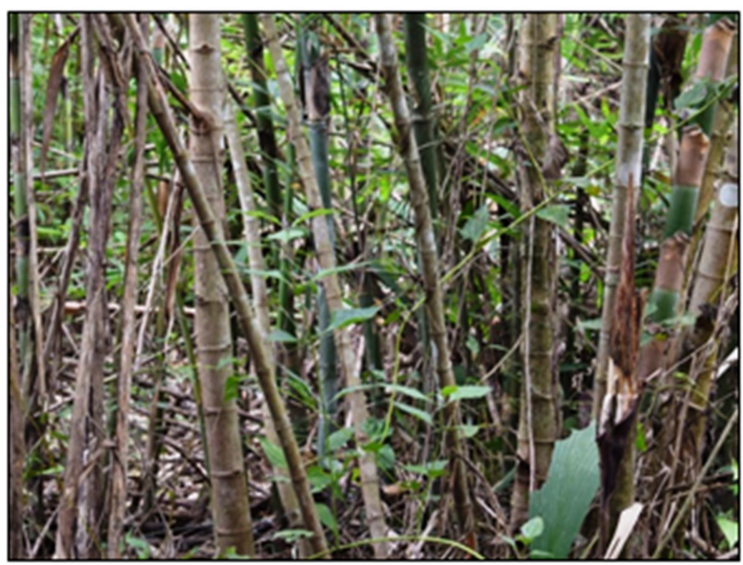

(g)

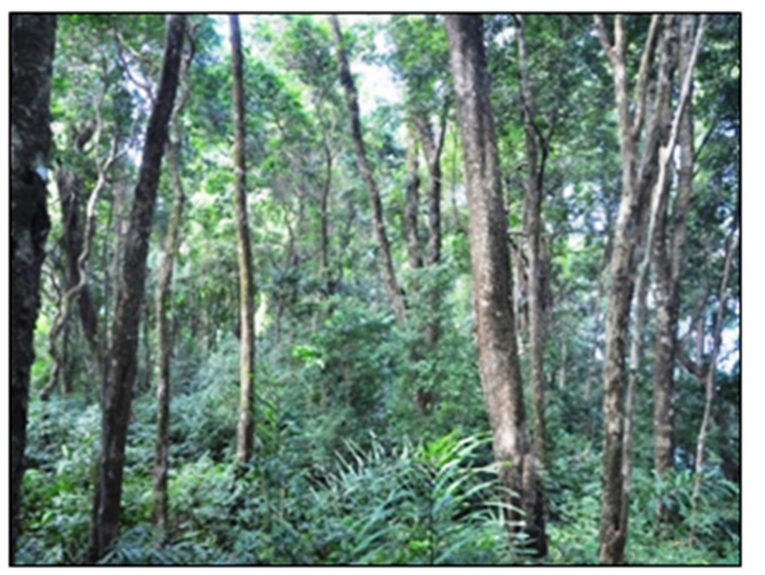

(j)

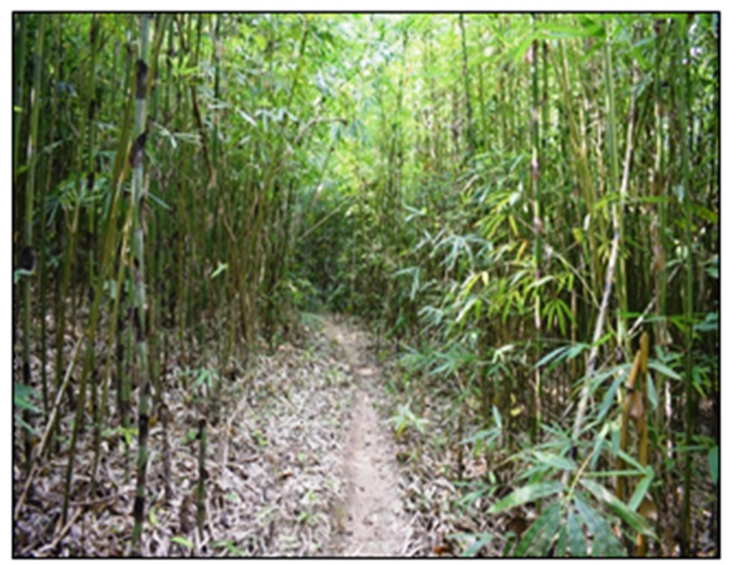

(h)

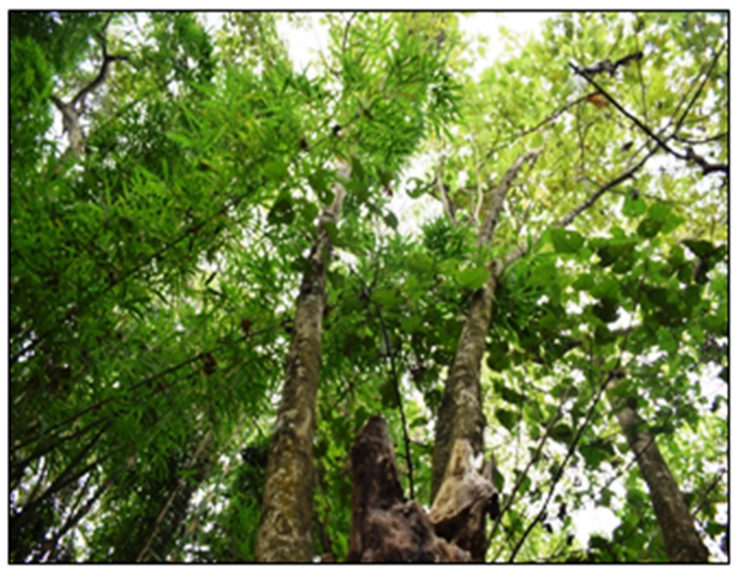

(k)

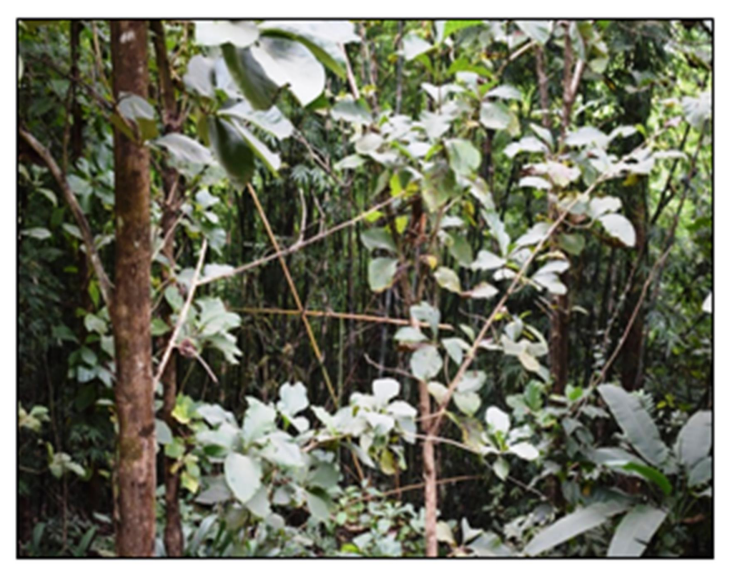

(i)

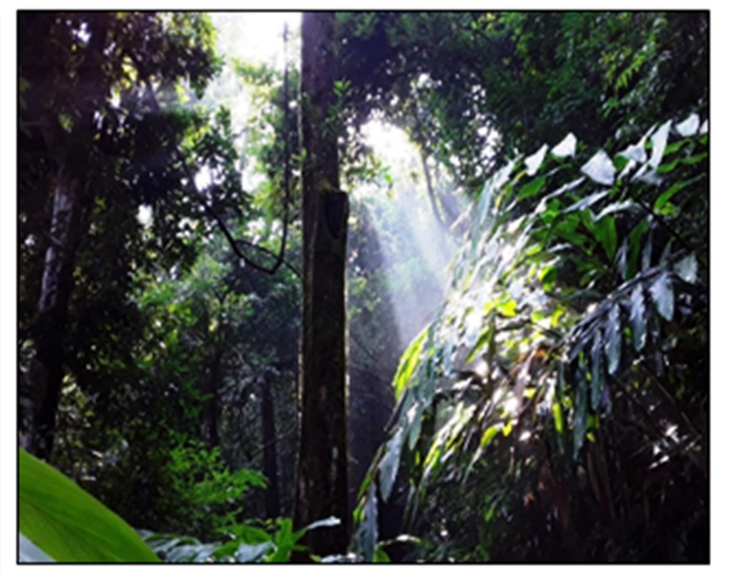

(l) 


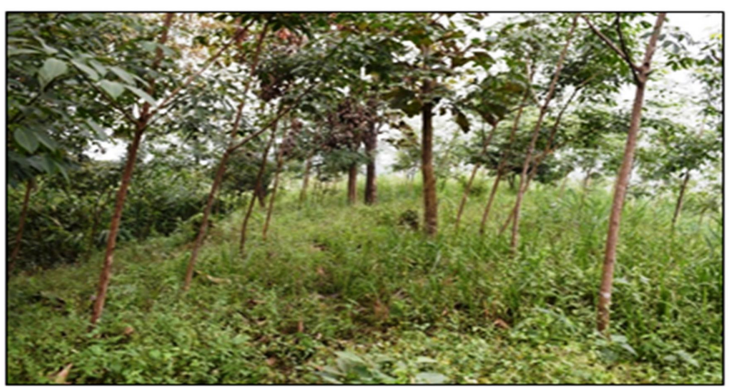

(m)

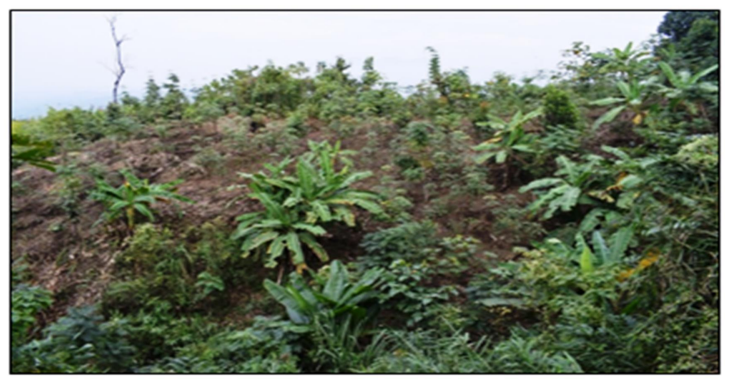

(o)

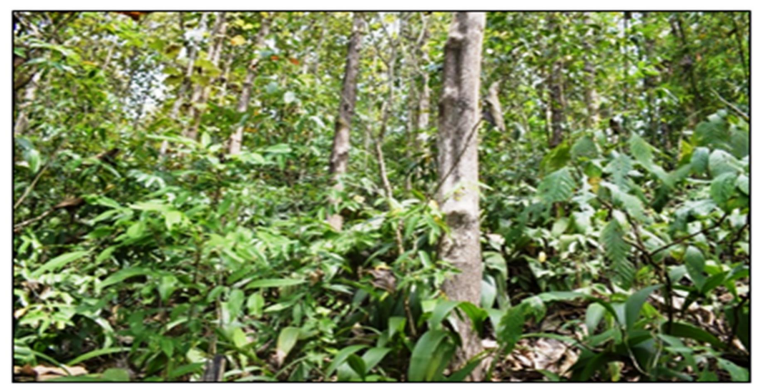

(n)

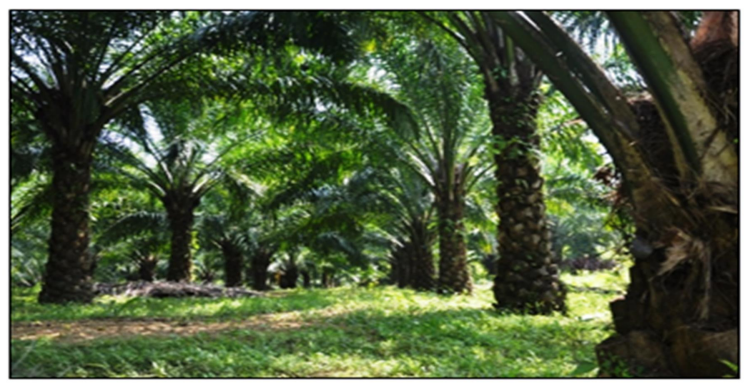

(p)

Plate 1: Different habitat types around DTR (a) Clearing of forest land (b) Burning of cleared forest for agriculture (c) Agricultural land before plantation of crop (d) Abandoned crop field (e) 1 years old forest habitat (f) \& (g) 2-3 years old forest (h) \& (i) < 5 years old forest (j) to (l) 10 to 15 years old forest (m) Rubber plantation (n) Teak plantation (o) Mixed farm (p) Oil palm plantation

\section{Conclusion}

Practice of shifting cultivation among forest dwellers in India has remained a matter of debate till date among conservationist, socio-economist and other stakeholders. While for several households it serve as source of income and the only means for livelihood sustenance for other it is the major cause of deforestation and soil degradation (Teegalapalli et al., 2009; Hossain, 2017; Yadav, 2013). Forest degradation along Dampa had aggravated in recent time due to indiscriminate forest clearance, lack of alternative livelihoods, mono-culture farming, shortening of the jhum fallow period etc. (Raman et al. 1998, Raman 2001; Sati and Rinawma, 2014; Mandal and Raman 2016). In the study, it was evident that presence of anthropogenic food sources like Oryza sativa, Benincasa hispida, Ipomoea batatas, Colocasia esculenta, Cucumis sativus, Cucurbita pepo etc. in adjacent crop fields of DTR serves as drivers of mammalian distribution in peripheral areas of DTR. Different ages of jhum fields aids for different purposes. Paddy hays in the recently abandoned crop fields ( 1 to 2 years old) were found to be ideal habitat for rodents with a burrow encounter rate of $3.56 / \mathrm{km}^{2}$, peafowls and also to some herbivorous species like barking deer and sambar as it provide with fresh leaves and grasses. The relative old crop fields (3-5 years old) with over $50 \%$ canopy cover were mostly used as trailing paths and shelter during noon time while the mature forest i.e. $5<$ years old were used by the larger mammalian species like bears, clouded leopard and primates. Plantation sites which comprises of rubber, betel, and mixed farms harbors a comparatively low number of species and were found to be rarely used by mammals except rodents. The perennial and seasonal streams flowing from DTR to the buffer regions also supports many species of amphibians along with crab eating mongoose, Indian palm civets and leopard cat.

The study highlights the necessity of livelihood diversification of locals around DTR to mitigate 

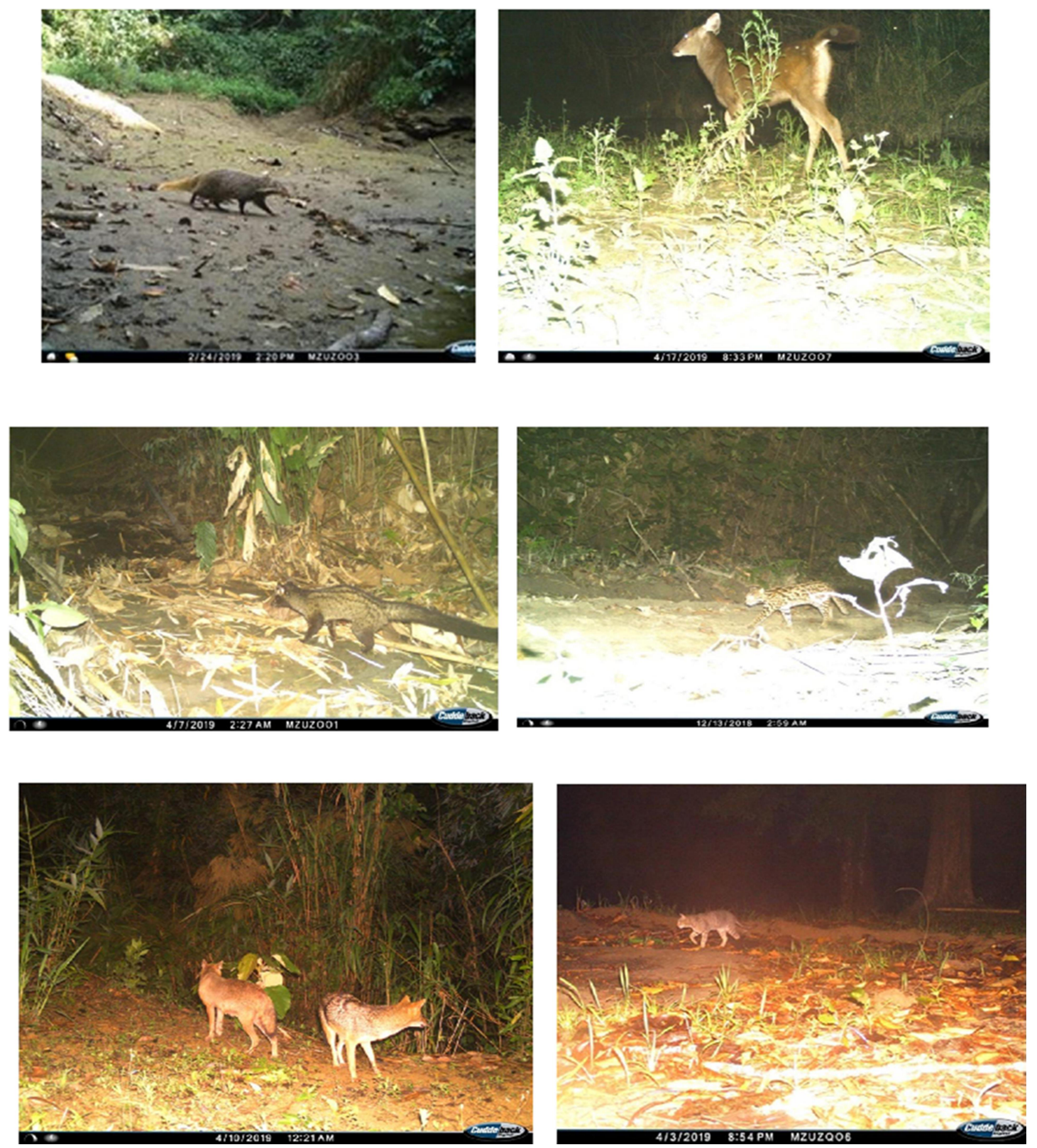

Plate 2: Images of mammalian species taken by camera trap in different ages of shifting cultivation

forest degradation, garden hunting and support impacts, agricultural plots embedded in a large prosperity for mammalian species. Engagement of forest matrix are known to increases spatial locals in on-farm activities and off-farm activities heterogeneity and promotes mammalian for transforming of jhum into more productive distribution. Abandoned jhum fields promotes systems and cultivation of high-value products survival of avifaunal species, small carnivores, (ginger, chilly, spices) was also suggested by Rasul reptiles and amphibians as it forms an excellent and Tripura (2016). Despite their several negative food chain among these group of animals (Medellin 113

Environment Conservation Journal 
and Equihua, 1998; Dalle et al., 2011; Rahman et al., 2011). It is therefore important to maintain and equilibrium between the primary forest patches and successional gradient of farm lands to achieve conservation goal and save-guard of the mammalian diversity beyond boundaries of protected areas..

\section{Acknowledgement}

The authors are thankful to the G.B. Pant National Institute of Himalayan Environment and Sustainable Development, Almora for providing the funds for this study through the project under National Mission on Himalayan Studies (NMHS). We are also grateful to the forest department of Mizoram for their necessary permission and support.

\section{Conflict of Interest}

The authors declare no conflict of Interest.

\section{Annexure-1}

Questionnaire for studying the nature and extend of anthropogenic pressure

1. Occupational backgrounds of villagers

2. Education levels of respondents

3. Age and gender of the respondents (40 and above/ 20-30/30-40)

4. Frequency of sighting animals along the buffer region (Day/ Week/ Month)

5. Time of sighting (Morning/ Noon/ Evening/ Night)

6. Season of sighting (Summer/ Winter/ Rainy)

7. Techniques and tools for hunting

8. Preference of meat sources (Domesticated/ bushmeat)

9. Population trends of animals over the last decade (Increased/ Decreased/ No-Idea)

10. Reason of hunting animal species and their preferred species

11. Age group and composition of hunters (1-2/3$5 /$ Over 5 persons)

12. Preferred time for hunting (Morning/ Noon/ Evening/ Night)

13. Average distance travelled by hunters for hunt

14. Average frequency of hunting (Once a week/ twice a week/ Once a month)

15. Time spend on one hunting (1-3 days/ a week)
16. Ethno- zoological medicinal uses of different parts (if known)

\section{References}

Adhikary, PP., Barman, D., Madhu, M., Dash, CJ., Jakhar, P., Hombegowda, HC., Naik, BS., Sahoo, DC., Beer, K. 2019. Land use and land cover dynamics with special emphasis on shifting cultivation in Eastern Ghats Highlands of India using remote sensing data and GIS. Environmental Monitoring and Assessment, 191: 315.

Apeldoorn, RV., Daem, M., Hawley, K., Kozakiewicz, M., Merriam, G., Nieuwenhuizen, W., Wegner, J. 1993. Footprints of small mammals. A field method of sampling data for different species Mammalia, 573.

Dalle, SP., Pulido, MT., Blois, SD. 2011. Balancing shifting cultivation and forest conservation: lessons from a 'sustainable landscape' in southeastern Mexico. Ecological Applications, 21(5):1557-1572.

Do, TV., Osawa A., Thang, NT. 2010. Recovery process of a mountain forest after shifting cultivation in North-western Vietnam. Forest Ecology and Management, 259: 16501659.

Farrell, LE., Roman, J., Sunquist, ME. 2000. Dietary separation of sympatric carnivores identified by molecular analysis of scats. Molecular Ecology, 9(10): 1583-1590.

Ferguson, BG., Vandermeer, J., Morales, H., Griffith, DM. 2001. Post-Agricultural Succession in El Petén, Guatemala. Conservation Biology, 17(3): 818-828.

Gemerden, BSV., Shu, GN and Olff, H. 2003. Recovery of conservation values in Central African rain forest after logging and shifting cultivation. Biodiversity and Conservation 12: 1553-1570.

Gouda, S., Sethy, J., Chauhan, NPS. 2016. First photo capture of Asiatic golden cat in Dampa Tiger Reserve, Mizoram, India. CAT news 64:26-27.

Hossain, MA. and Ahmad, A. 2017. Livelihood status of hill dwellers in Bandarban, Bangladesh. International Journal of Business, Management and Social Research, 03(01): 154-161. Crossref:

Kendawang, JJ., Tanaka, S., Ishihara, J., Shibata, K., Sabang, J., Ninomiya, I., Ishizuka, S., Sakurai, K. 2004. Effects of shifting cultivation on soil ecosystems in Sarawak, Malaysia, Soil Science and Plant Nutrition, 50(5): 677687, DOI: 10.1080/00380768.2004.10408524.

Khisa, SK. and Mohiuddin, M. 2015. 'Shrinking jhum and changing livelihoods in the Chittagong Hill Tracts of Bangladesh', pp.41-96. In Erni, C. (2015) Shifting cultivation, livelihood and food security: New and old challenges for indigenous peoples in Asia. 41-96. Bangkok, Thailand: FAO; IWGIA; AIPP. 
Impact of shifting cultivation on mammalian diversity and distribution

Kumar, P. and Singh, P. 2018. Conservation assessment of two rare gingers (Zingiberaceae) from Dampa Tiger Reserve, Mizoram, India. Journal of Threatened Taxa, 10(5):11599-11605.

Lalrinchhana, C. and Solanki, GS. 2015. Lizard (Reptilia: Sauria) diversity of Dampa Tiger Reserve, Mizoram, India. Science Vision 15(1): 19-28.

Mandal, J. and Raman, TRS. 2016. Shifting agriculture supports more tropical forest birds than oil palm or teak plantations in Mizoram, northeast India. The Condor: Ornithological Applications, 118(2):345-359. DOI: http://dx.doi.org/10.1650/CONDOR-15-163.1.

Medellin, RA. and Equihua, M. 1998. Mammal species richness and habitat use in rainforest and abandoned agricultural fields in Chiapas, Mexico. Journal of Applied Ecology, 35:13-23.

Mukul, SA. and Herbohn, J. 2016. The impacts of shifting cultivation on secondary forests dynamics in tropics: A synthesis of the key findings and spatio-temporal distribution of research. Environmental Science and Policy, 55: 167-177.

Naughton-Treves, L., Mena, JL., Treves, A., Alvarez, N., Radeloff, VC. 2003. Wildlife survival beyond park boundaries: The impact of slash-and-burn agriculture and hunting on mammals in Tambopata, Brazil. Conservation Biology, 17: 1106-1117.

Odyuo, N., Sinha, BK., Murugesan, M., Uddin, A. 2018. A new species of Begonia L. (Begoniaceae) from Dampa Tiger Reserve, Mizoram, India. Pleione, 12(1): 99 - 104.

Omeja, P.A., Lawes, MJ., Corriveau, A., Valenta,K., Sarkar, D., Paim, FP., Chapman, CA. 2016. Recovery of tree and mammal communities during large-scale forest regeneration in Kibale National Park, Uganda. Biotropica, 48(6): 770-779.

Rahman, SA., Rahman, MF., Sunderland, T. 2011. Causes and consequences of shifting cultivation and its alternative in the hill tracts of eastern Bangladesh. Agroforest System. DOI 10.1007/s10457-011-9422-3.

Raman, TRS. 2001. Effect of slash-and-burn shifting cultivation on rainforest birds in Mizoram, Northeast India. Conservation Biology, 15(3): 685-698.

Raman, TRS., Rawat, GS., Johnsingh, AJT. 1998. Recovery of tropical rainforest avifauna in relation to vegetation succession following shifting cultivation in Mizoram North-east India. Journal of Applied ecology, 35: 214-231.

Rasul, G. and Tripura, NBK. 2016. Achieving the sustainable development goals in Chittagong Hill Tracts - Challenges and opportunities. ICIMOD Working Paper 2016/12. Kathmandu: ICIMOD.
Reid, FA. 1997. A Field Guide to the Mammals of Central America and Southeast Mexico, Oxford University Press, New York.

Rich, LN., Miller, DAW., Muñozb, DJ., Robinsonc, HS., McNutt, JW., Kelly, MJ. 2019. Sampling design and analytical advances allow for simultaneous density estimation of seven sympatric carnivore species from camera trap data. Biological Conservation, 233: 12-20.

Sahoo, UK., Lalremruata, J., Jeeceelee, L., Lalremruati, JH., Lalliankhuma, C., Lalramnghinglova, H. 2010. Utilization of non-timber forest products by the tribal around Dampa Tiger Reserve in Mizoram. The Bioscan, 3:721-729.

Sati, VP. and Rinawma, P. 2014. Practices of shifting cultivation and its implications in Mizoram, North-East India: A review of existing research. Nature and Environment, 19(2): 179-187.

Schmeller, DS. 2015. Towards a global terrestrial species monitoring program. Journal of Natural Conservation, 25: $51-57$.

Singh, P. and Macdonald, DW. 2017. Populations and activity patterns of clouded leopards and marbled cats in Dampa Tiger Reserve, India. Journal of Mammalogy, 98(5):14531462. DOI:10.1093/jmammal/gyx104.

Solanki, GS., Lalchhandama, D., Lalnunpuii. 2016. Use pattern of faunal resources by tribal and its impact on biodiversity in Dampa Tiger Reserve in Mizoram, India. Journal of Bioresources 3(1): 24-29.

Steenweg, R., Hebblewhite, M., Kays, R., Ahumada, J., Fisher, JT., Burton, C., Rich, LN., 2017. Scaling-up camera traps: monitoring the planet's biodiversity with networks of remote sensors. Frontiers in Ecology and Evolution, 15: $26-34$

Teegalapalli, K., Gopi, GV., Samal, PK. 2009. Forest recovery following shifting cultivation: an overview of existing research. Tropical Conservation Science, 2(4): 374-387.

Walsh, AJ. 2015. Carnivore diet identification through scat and genetic analysis in Namibia, Africa. Honors Theses and Capstones, 257. https://scholars.unh.edu/honors/257.

Yadav, PK. 2013. Slash-and-burn agriculture in north-east India. Expert Opinion in Environment and Biology. 2:1. doi:10.4172/2325- 9655.1000102.

Yadav, PK., Kapoor, M., Sarma, K. 2012. Impact of slash-andburn agriculture on forest ecosystem in garo hills landscape of Meghalaya, North-East India. Journal of Biodiversity and Manage Forestry, 1:1. http://dx.doi.org/10.4172/23274417.1000102 